\title{
Susceptibility to citrus canker caused by Xanthomonas axonopodis pv. citri depends on the nuclear genome of the host plant
}

\author{
Hiroshi Shiotani · Terutaka Yoshioka • \\ Masashi Yamamoto $\cdot$ Ryoji Matsumoto
}

Received: 29 May 2007/ Accepted: 20 September 2007/Published online: 26 January 2008

(C) The Phytopathological Society of Japan and Springer 2008

\begin{abstract}
Susceptibility to Xanthomonas axonopodis pv. citri of a citrus cybrid, in which the nuclear and cytoplasmic genomes were derived from Citrus sinensis and $C$. unshiu, respectively, was evaluated. Bacterial growth in the leaves of the cybrid was similar to that in $C$. sinensis after pin-prick inoculation throughout the experiment, whereas growth was greater than that in $C$. unshiu from 8 days after inoculation. Lesion expansion and pustules that later developed from the lesions on the cybrid and on $C$. sinensis also appeared to be greater than those on C. unshiu. The incidence of citrus canker disease caused by the bacteria on the cybrid trees was in the field was equivalent to that on $C$. sinensis but was severer than on $C$. unshiu. These results indicate that the nuclear genome of the cybrid plays a critical role in susceptibility to citrus canker disease. However, the pathogenicity gene $p t h A$ of the bacteria is not likely to be involved in the difference in susceptibility to the bacteria between $C$. unshiu and $C$. sinensis because their susceptibility to a pthA-deficient mutant of the bacteria also differs.
\end{abstract}

\footnotetext{
H. Shiotani $(\bowtie)$

Kuchinotsu Citrus Research Station,

National Institute of Fruit Tree Science, 954 Otsu,

Minamishimabara, Nagasaki 859-2501, Japan

e-mail: hiroshi@affrc.go.jp

T. Yoshioka

National Institute of Fruit Tree Science, Ibaraki, Japan

M. Yamamoto

Faculty of Agriculture, Kagoshima University,

Kagoshima, Japan

R. Matsumoto

Faculty of Agriculture, Saga University, Saga, Japan
}

Keywords Xanthomonas axonopodis pv. citri . Citrus cybrid

\section{Introduction}

The causal agent of citrus canker disease, Xanthomonas axonopodis pv. citri, has pathogenicity gene pthA, which belongs to the avrBs3/pthA (avirulence/pathogenicity) gene family and is required for full virulence on citrus plants (Kanamori and Tsuyumu 1998; Swarup et al. 1992). The transient expression of $p t h A$ in the leaves of Citrus species results in citrus canker symptoms involving cell hypertrophy, division, and death, which indicates that PthA functions inside the plant cell as a specific plant signal (Duan et al. 1999).

$X$. axonopodis pv. citri has a broad host range among members of the Rutaceae, although differences in field resistance exist among Citrus species (Gottwald and Graham 2000). The resistance of citrus plants has been considered as not due to active physiological resistance because all plants were highly susceptible after artificial inoculations (Brunings and Gabriel 2003). However, another gene in the avrBs3/pthA family, hssB3.0, was recently isolated from $X$. axonopodis pv. citri and characterized as responsible for the host-specific suppression of virulence, which induces a defense response specifically on cultivars of $C$. grandis (Shiotani et al. 2000, 2007).

The avrBs3/pthA family is a group of highly conserved members prevalent in the genus Xanthomonas. The genes in this family confer two functions to the bacteria avirulence and virulence to the host plants with and without, respectively, the corresponding resistance gene (Gabriel 1999; Leach and White 1996). Both functions are highly dependent on the type III protein secretion system, which is 
encoded by the $h r p$ gene cluster in the bacterial genome (Büttner and Bonus 2002). The functions of these gene products in the host plant have been deduced from their unique protein structure, which is composed of a central region of multiple, nearly identical repeated sequences of 34 amino acid residues, three nuclear localization signals (NLSs), and an acidic activation domain (AAD) in the carboxyl terminus (Ponciano et al. 2003). On the basis of the structure of the NLSs and the AAD, AvrBs3/PthA proteins are predicted to function in the plant nucleus (Szurek et al. 2001; Yang et al. 2000; Yang and Gabriel 1995). Mutations in the structures of both the NLSs and the AAD abolish the defense responses and reduce the ability of the pathogen to cause disease in various plant-pathogen interactions.

A citrus cybrid, which consists of the $C$. sinensis nuclear genome and the $C$. unshiu cytoplasmic genome, was produced to investigate cytoplasmic male sterility that probably originated from C. unshiu (Yamamoto and Kobayashi 1995). C. unshiu and C. sinensis have been considered to be moderately resistant and highly susceptible, respectively, to citrus canker disease (Matsumoto and Okudai 1990). The cytoplasm has been shown to be involved in cytoplasmic male sterility and vital plant functions such as photosynthesis, sugar and fatty acid metabolism, ATP production, and disease resistance (Kadowaki et al. 1990; Mazouz et al. 2002; Otani et al. 2002). Because there is little cytoplasmic information in citrus, this cybrid can be an ideal material for studying cytoplasmic involvement in resistance to citrus canker disease. We report here that the nuclei of host plants also play a critical role in this disease through experiments with this cybrid and its parent citrus plants.

\section{Materials and methods}

Plant materials

The citrus cybrid was produced previously by electrofusion between protoplasts derived from the nucellar embryo of Citrus unshiu MARC cv. Juman and a mesophyll cell of $C$. sinensis Osbeck cv. Washington naval orange (Yamamoto and Kobayashi 1995). Leaf morphology of the cybrid was similar to that of the mesophyll parent $C$. sinensis. Flower characteristics of the cybrid were almost identical to those of $C$. sinensis except for the number of stamens (Yamamoto et al. 2001). The cybrid consists of the $C$. sinensis nuclear genome and $C$. unshiu cytoplasmic genome. Scions of the cybrid and its parent plants used for the inoculation test were grafted onto potted two- year-old rootstocks Poncirus trifoliata Raf. (trifoliate orange).
Disease was assessed in each of three trees, planted eight years before, in the orchard at the Kuchinotsu Citrus Research Station.

\section{Bacterial strains}

A strain KC21 of Xanthomonas axonopodis pv. citri and its derivative mutant $\mathrm{KC} 21 \mathrm{~T} 14$, in which the pathogenicity gene pthA-KC21 was disrupted by Tn5 insertion, were used in this study (Shiotani et al. 2007). The bacterial strains were cultured in yeast-peptone (YP) medium at $27^{\circ} \mathrm{C}$. For solid medium, $1.5 \%$ agar was added to these media. The final concentration of the antibiotics incorporated into media was $50 \mu \mathrm{g}$ per $\mathrm{ml}$ for kanamycin for selecting resistant strain KC21T14. The gene pthA-KC21 was deposited in GenBank under accession number AB206388.

\section{Inoculation test}

The sensitivity of the cybrid and its parents plants to $X$. axonopodis pv. citri were evaluated after pin-prick inoculation of attached leaves with the bacterial strains as previously reported (Shiotani et al. 2000). Bacterial strains were grown on Wakimoto's potato semi-synthetic medium with $1.5 \%$ agar (PSA medium) (Wakimoto 1967 ) at $27^{\circ} \mathrm{C}$ for 1 day. Bacteria were suspended in $0.85 \% \mathrm{NaCl}$ at a concentration of $10^{8}$ cells $/ \mathrm{ml}$, and a drop of the suspension was placed on an attached, mature leaf of each citrus plant. Immediately after an insect pin $(0.5 \mathrm{~mm}$ in diameter) was inserted into the leaves through the bacterial suspension, the inoculum drops were wiped off with sterile cotton. The inoculated plants were then grown in a greenhouse. The diameter of circular lesions, including cork tissue and water-soaked margin, was measured after inoculation. For observing bacterial growth in planta, the populations in the lesions at $0,1,2,3,4,8,16$, and 32 days after pin-prick inoculation were determined after removing the lesion with a cork-borer. The excised tissue was macerated in $0.85 \% \mathrm{NaCl}$, and the suspension was plated on a semiselective XCSM medium (Shiotani et al. 2000).

Disease development in the orchard

Disease development was investigated in July 2003 on 20 shoots for each tree selected in order of lesion abundance, with the following index: of 0 , no lesions; $1,1-3$ lesions; 3 , 4-10 lesions; 5, 11-20 lesions; 7, more than 20 lesions. 
Disease severity (DS) was calculated from the sum of the index numbers (SI) as follows:

$\mathrm{DS}=\mathrm{SI} /(20 \times 7) \times 100$

\section{Results and discussion}

Susceptibility to citrus canker disease depends on the nuclear genome of the host plant

The sensitivity of the cybrid and its parents plant, Citrus unshiu (cv. Juman) and C. sinensis (cv. Washington navel orange), to $X$. axonopodis pv. citri was evaluated after pin-prick inoculation of attached leaves with the bacterial strain KC21. Water-soaked lesions were elicited on all citrus plants within 4 days after inoculation. Pustules later developed from the lesions; however, those on C. unshiu appear to have developed less than those on the cybrid and C. sinensis (Fig. 1). In all the plants tested, populations of strain KC21 increased similarly for the first 4 days after prick inoculation to approximately $3.4 \times 10^{5} \mathrm{CFU}$ per lesion (Fig. 2a). After 4 days, the rate of multiplication on C. unshiu differed from those on the cybrid and $C$. sinensis. After 16 days, the bacterial populations decreased on $C$. unshiu, but not on the cybrid nor $C$. sinensis. No significant difference in the bacterial population was observed between the cybrid and $C$. sinensis throughout the experiment. These results indicate that the susceptibility to citrus canker disease in the leaf tissue of the cybrid plant, which is equivalent to that of $C$. sinensis, might depend on the nuclear genome of the species. Disease severity on the cybrid trees in the orchard was also similar to that on $C$. sinensis trees (Table 1). Citrus cultivars and species with greater frequency, size, and duration of leaf flushes are more susceptible to citrus canker in the field than are less vigorous cultivars or those with more rapidly maturing foliage (Gottwald et al. 1993). Because no difference in vigor has been observed between the cybrid and $C$. sinensis trees, the identical susceptibility of the cybrid leaf tissue and $C$. sinensis to $X$. axonopodis pv. citri appeared to be related directly to the field susceptibility of the cybrid trees to citrus canker. Cytoplasm can contribute disease resistance (Mazouz et al. 2002; Ohtani et al. 2002); however, the moderate resistance to citrus canker of $C$. unshiu might be independent of its cytoplasmic genome.

Different rates of lesion expansion between on leaves of the cybrid and $C$. sinensis were observed (Table 2). This observation suggests that this difference depends not on their nuclear but on the cytoplasmic genomes. However, this difference in lesion expansion does not mean that the
Fig. 1 Canker symptoms on abaxial leaf surface of Citrus sinensis, C. unshiu, and the cybrid between them. Symptoms developed 40 days after prick inoculation with strain $\mathrm{KC} 21$ and its derivative pthA-KC21-deficient mutant KC21T14 of Xanthomonas axonopodis pv. citri. Bar represents $1 \mathrm{~mm}$
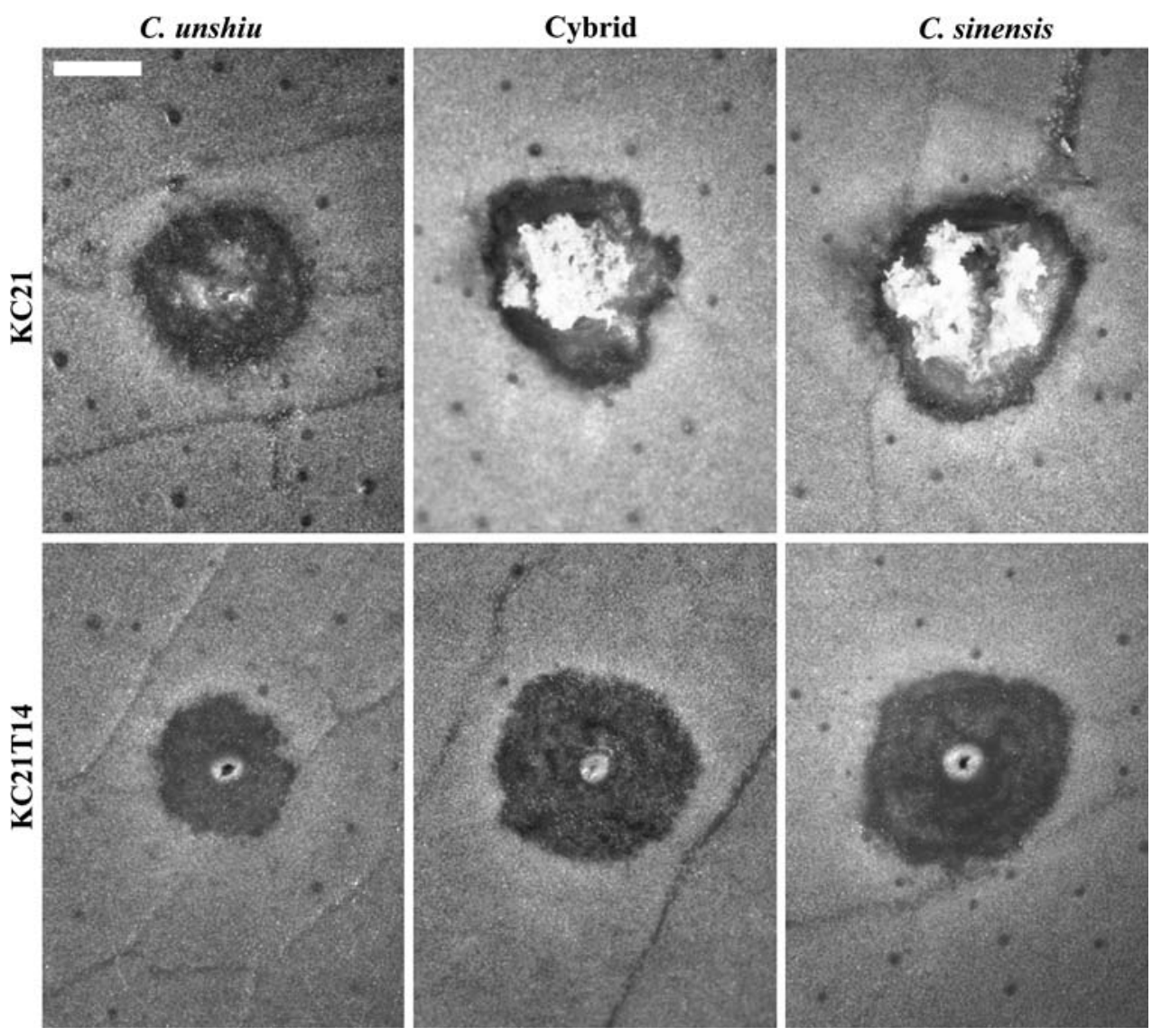


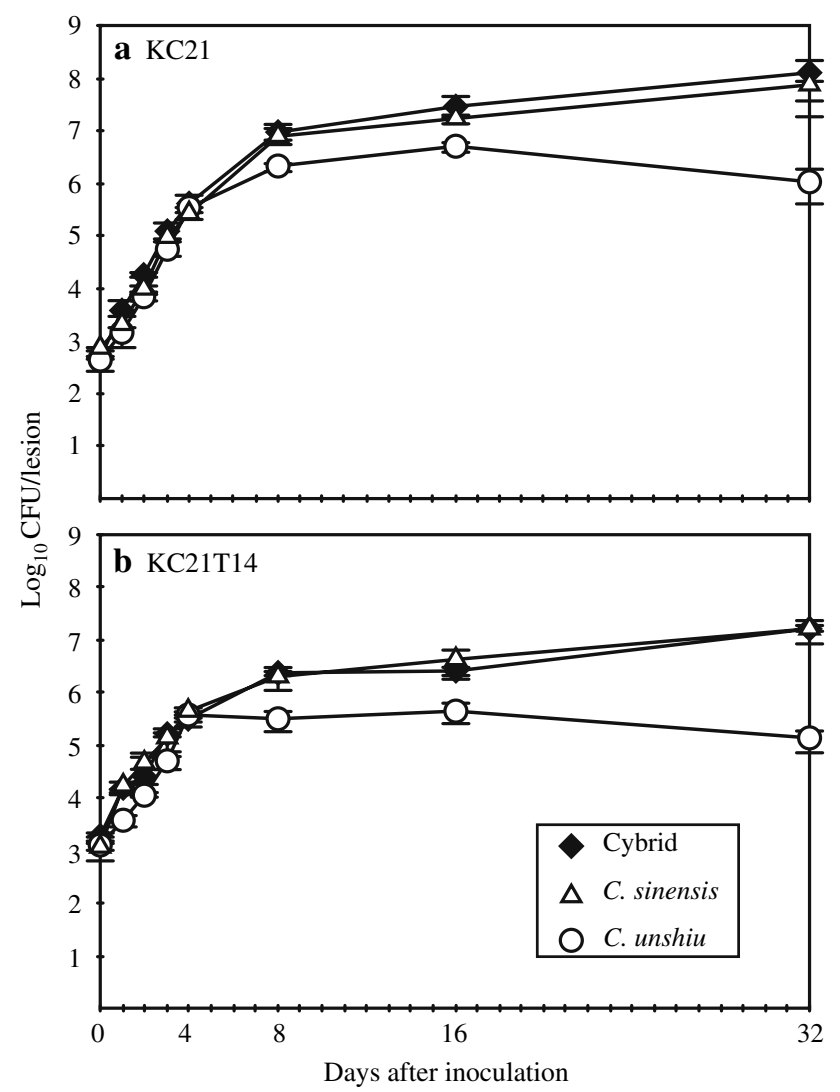

Fig. 2 Time course of bacterial growth in the leaves of citrus plants. Leaves of Citrus sinensis, C. unshiu, and their cybrid were prick inoculated with strain $\mathrm{KC} 21$ (a) of Xanthomonas axonopodis pv. citri and its derivative mutant $\mathrm{KC} 21 \mathrm{~T} 14$ (b), in which the pathogenicity gene pthA-KC21 was disrupted by Tn5 insertion. Leaves were sampled for 32 days after inoculation. The values are means from five repetitions, and vertical bars represent the standard error at each sampling time

Table 1 Severity of citrus canker disease on Citrus species and their cybrid

\begin{tabular}{ll}
\hline Plant & Disease severity $^{\mathrm{a}}$ \\
\hline C. unshiu & $3.1 \pm 0.1 \mathrm{~b}$ \\
C. sinensis & $4.8 \pm 0.5 \mathrm{a}$ \\
Cybrid & $5.0 \pm 0.4 \mathrm{a}$ \\
\hline
\end{tabular}

${ }^{a}$ Disease severity on each plant was investigated in July 2003, on 20 shoots for each tree selected in order of lesion abundance, index: of 0 , no lesions; 1, 1-3 lesions; 3, 4-10 lesions; 5, 11-20 lesions; 7, more than 20 lesions. The mean value and standard error of three trees is presented. Those followed by unlike letters differ significantly at $\alpha=0.01$ according to the Tukey-Kramer honestly significant difference test

susceptibility to citrus canker differs between these plants because bacterial growth on these two was similar for 32 days after inoculation (Fig. 2a).
Table 2 Lesion diameters on leaves of Citrus species and their cybrid $40 \mathrm{~d}$ after prick-inoculation with either wild-type strain $\mathrm{KC} 21$ and its Tn5 mutant KC21T14 of Xanthomonas axonopodis pv. citri

\begin{tabular}{lll}
\hline Plant & \multicolumn{2}{l}{ Lesion diameter $(\mathrm{mm})^{\mathrm{a}}$} \\
\cline { 2 - 3 } & $\mathrm{KC} 21$ & KC21T14 \\
\hline C. unshiu & $2.63 \pm 0.06 \mathrm{c}$ & $1.69 \pm 0.27 \mathrm{~b}$ \\
C. sinensis & $3.56 \pm 0.05 \mathrm{a}$ & $2.34 \pm 0.20 \mathrm{a}$ \\
Cybrid & $3.07 \pm 0.07 \mathrm{~b}$ & $2.23 \pm 0.13 \mathrm{a}$ \\
\hline
\end{tabular}

${ }^{a}$ Each value represents the mean diameter $(\mathrm{mm})$ and standard error of 16 lesions for each strain on attached leaves. Those followed by unlike letters differ significantly at $\alpha=0.01$ according to the TukeyKramer honestly significant difference test

Pathogenicity gene pthA of $X$. axonopodis pv. citri is independent of differences in susceptibility of $C$. unshiu and $C$. sinensis to the bacteria

The pathogenicity gene pthA, essential for $X$. axonopodis pv. citri to cause citrus canker disease, confers the ability to rupture the epidermis and elicit cankers on citrus. Thus, PthA may be involved in the difference in pustule development observed between $C$. sinensis and $C$. unshiu, in which nuclear genomes directly affect the susceptibility to citrus canker disease. To determine the involvement of $p t h A$ in the different pustule development, we produced a mutant KC21T14, derived from a strain KC21 of X. axonopodis pv. citri, in which pathogenicity gene pthA-KC21 was disrupted by insertion of $\mathrm{Tn} 5$, was used to prick inoculate the leaves of $C$. unshiu and $C$. sinensis. The mutant KC21T14 elicited water-soaked lesions on their leaves, but no pustules were observed on the lesions throughout the experiment (Fig. 1). Also, the mutant grew significantly less in the lesions on both Citrus species than did the wild strain $\mathrm{KC} 21$ from 8 days after inoculation (Fig. 2b). Although lesions on the cybrid and C. sinensis expanded at different rates after inoculation with a wild strain KC21, the pthA-KC21-deficient mutant KC21T14 induced lesions of the same size on both (Table 2). This suggests that pthA-KC21 might be associated in the different lesion expansion.

The differences in bacterial growth and lesion expansion were still observed between on $C$. unshiu and $C$. sinensis even after the inoculation with the mutant KC21T14 (Fig. $2 \mathrm{~b}$ and Table 2). These results indicates that the pathogenicity gene pthA-KC21 in the strain $\mathrm{KC} 21$ is independent of the difference in susceptibility to the bacteria between these Citrus species although this gene contributes to eliciting the distinctive canker symptoms (Brunings and Gabriel 2003). In addition, the bacterial population and lesion expansion on the cybrid after inoculation with mutant KC21T14 was the same as those on 
C. sinensis not on $C$. unshiu. These results strongly suggest that the nuclear genome of $C$. sinensis confers greater susceptibility to $X$. axonopodis pv. citri.

Strain KC21 harbors three genes in the avrBs3/pthA family other than $p t h A-K C 21$ : $p B 3.1, p B 3.7$, and $h s s B 3.0$ (Shiotani et al. 2007). Of these, hssB3.0 is involved in the host-specific suppression of virulence, so that a defense response is elicited in $C$. grandis. Because all these family genes encode NLS sequences that are identical to those of pthA, their protein products could also be transferred into the nucleus of host plants. However, there is no evidence that any of the avrBs3/pthA family genes are involved in the moderate resistance of $C$. unshiu to $X$. axonopodis pv. citri. According to the gene-for-gene theory (Gabriel 1999), the gene product of $h s s B 3.0$ might be recognized by a cognate resistance gene. Further studies will need to be done to elucidate the resistance gene in Citrus genus.

\section{References}

Brunings AM, Gabriel DW (2003) Xanthomonas citri: breaking the surface. Mol Plant Pathol 4:141-157

Büttner D, Bonas U (2002) Getting across-bacterial type III effector proteins on their way to the plant cell. EMBO J 21:5313-5322

Duan YP, Castañeda A, Zhao G, Erdos G, Gabriel DW (1999) Expression of a single, host-specific, bacterial pathogenicity gene in plant cells elicits division, enlargement, and cell death. Mol Plant Microbe Interact 12:556-560

Gabriel DW (1999) The Xanthomonas avr/pth gene family. In: Stacey G, Keen NT (ed) Plant-microbe interactions vol. 4. APS Press, St. Paul, pp 39-55

Gottwald TR, Graham JH, Civerolo EL, Barrett HC, Hearn CJ (1993) Differential host range reaction of citrus and citrus relatives to citrus canker and citrus bacterial spot determined by leaf mesophyll susceptibility. Plant Dis 77:1004-1009

Gottwald TR, Graham JH (2000) Canker. In: Timmer LW, Garnsey SM, Graham JH (eds) Compendium of citrus diseases, 2nd edn. APS Press, St. Paul, pp 5-7

Kanamori H, Tsuyumu S (1998) Comparison of nucleotide sequences of canker-forming and non-canker-forming pthA homologues in Xanthomonas campestris pv. citri. Ann Phytopathol Soc Jpn 64:462-470

Kadowaki K, Suzuki T, Kazama S (1990) A chimeric gene containing the 5' portion of atp6 is associated with cytoplasmic malesterility. Mol Gen Genet 224:10-16
Leach JE, White FF (1996) Bacterial avirulence genes. Annu Rev Phytopathol 34:153-179

Matsumoto R, Okudai N (1990) Inheritance of resistance to bacterial canker disease in citrus (in Japanese). J Jpn Soc Hortic Sci 59:914

Mazouz H, Saadaoui EM, Jlibene M, Bouami FE (2002) Evidence of cytoplasm contributing resistance to specific groups of virulence of Mycosphaerella graminicola (Fuckel) Shroeter in two bread wheat genotypes (Triticum aestivum L.). Field Crop Res 79:197206

Ohtani K, Yamamoto H, Akimitsu K (2002) Sensitivity to Alternaria alternata toxin in citrus because of altered mitochondrial RNA processing. Proc Natl Acad Sci USA 99:2439-2444

Ponciano G, Ishihara H, Tsuyumu S, Leach JE (2003) Bacterial effectors in plant disease and defense: keys to durable resistance? Plant Dis 87:1272-1282

Shiotani H, Fujikawa T, Ishihara H, Tsuyumu S, Ozaki K (2007) A pthA homolog from Xanthomonas axonopodis pv. citri responsible for host-specific suppression of virulence. J Bacteriol 189:3271-3279

Shiotani H, Ozaki K, Tsuyumu S (2000) Pathogenic interactions between Xanthomonas axonopodis pv. citri and cultivars of Pummelo (Citrus grandis). Phytopathology 90:1383-1389

Swarup S, Yang Y, Kingsley MT, Gabriel DW (1992) A Xanthomonas citri pathogenicity gene pthA, pleiotropically encodes gratuitous avirulence on nonhosts. Mol Plant Microbe Interact 5:204-213

Szurek B, Marois E, Bonus U, Van den Ackerveken G (2001) Eukaryotic features of the Xanthomonas type III effector AvrBs3: protein domains involved in transcriptional activation and the interaction with nuclear import receptors from pepper. Plant J 26:523-534

Wakimoto S (1967) Some characteristics of citrus canker bacteria, Xanthomonas citri (Hasse) Dowson, and the related phages isolated from Japan. Ann Phytopathol Soc Jpn 33:301-310

Yamamoto M, Kobayashi S (1995) A cybrid plant produced by electrofusion between Citrus unshiu (Satsuma mandarin) and C. sinensis (sweet orange). Plant Tissue Cult Lett 12:131-137

Yamamoto M, Kobayashi S, Yoshioka T, Matsumoto R (2001) Cybridization in Citrus unshiu Marc. (satsuma mandarin) and $C$. sinensis (L.) Osbeck (sweet orange). In: Nagata T, Bajaj YPS (eds) Somatic hybridization in crop improvement II. Biotechnology in agriculture and forestry vol. 49. Springer, Berlin pp 124-138

Yang Y, Gabriel DW (1995) Xanthomonas avirulence/pathogenicity gene family encodes functional plant nuclear targeting signals. Mol Plant Microbe Interact 8:627-631

Yang B, Zhu W, Johnson LB, White FF (2000) The virulence factor AvrXa7 of Xanthomonas oryzae pv. oryzae is a type III secretion pathway-dependent nuclear-localized double-stranded DNAbinding protein. Proc Natl Acad Sci USA 97:9807-9812 